\title{
Analysis of Student Ability in Solving PISA-Like Math Problems: a case study in SMPN 8 Banda Aceh, Indonesia
}

\author{
Haris H. Ismail ${ }^{1 *}$, M. Duskri ${ }^{2}$ C. M. Zubainur ${ }^{1}$, Said Munzir ${ }^{1}$ \\ ${ }^{1}$ Universitas Syiah Kuala, Faculty of Teacher Training and Education, \\ Department of Mathematics Educations \\ Banda Aceh 23111, Indonesia \\ ${ }^{2}$ Universitas Islam Negeri Ar-Raniry, Faculty of Tarbiyah and Teacher Training, \\ Department of Mathematics Educations \\ Banda Aceh 23111, Indonesia
}

\begin{abstract}
:
The Programme International for Student Assessment (PISA) has become a tool in determining the quality of education in a certain country. Unfortunately, Indonesian students still have difficulties in solving PISA problems. In an effort to improve students' ability in Indonesia to solve PISA questions, we need to analyze their difficulties in solving contextual problems. In this study, we have developed PISA-like problems by taking into account the contextual environment of students and current Indonesian curriculum. Forty-eight PISA-like math problems in Bahasa Indonesia have been developed consisting of sixteen questions level one, sixteen questions level two, and sixteen questions level three. Then, those PISA-like math problems were used to assess the students' ability (case study in SMPN 8 Banda Aceh, Indonesia). Our study revealed that the ability of students is still very low in understanding the information given in the problems. The students' ability in the mathematical process and decoding are still quite low. Students should practice the PISA-like problems in the teaching-learning process in order to improve their abilities in PISA.
\end{abstract}

Keywords: PISA, math questions, contextual problem, students' ability

\section{Introduction}

Programme International for Student Assessment (PISA) is to measure the students' ability of mathematical literacy, to formulate, employ, and interpret mathematics in a variety of context-based problems [1]. The PISA has become the main conversation in determining education policies in various countries [2]. This is because the PISA results are closely related to the education curriculum a country. The quality of education of a country is influenced by the alignment of its curriculum with the standard aspects of PISA assessment. For example, in Australia, the PISA score is very good on uncertainty and data content, namely on the opportunities and interpretation of data, indicating that these topics exist in the curriculum and are taught very well in schools [3].

Indonesia is one of the countries that has considered PISA to evaluate the quality of education. Like other countries, the Indonesian government has made various efforts to improve student literacy skills by improving the previous curriculum (namely by KTSP curriculum) into the new curriculum (called 2013 curriculum). However, the ability of Indonesian students in solving PISA is still below the OECD average. The ability of Indonesian students in PISA has not been increased significantly [4]. The improvement of student ability in solving PISA questions is still low. The average score from Indonesian students in 2012 was 375 . The score was increased to 386 by 2015 , just only 11 points increased [5]. These results reflect that the ability of Indonesian students to apply mathematics as a tool to solve contextual problems is still very low compared to other countries in the OECD.

The previous research found that the difficulties of Indonesian students in solving PISA problems are difficulties in understanding problems, resolving context-based problems, and transforming them into 
mathematical problems. This situation was happened because the majority of teachers used the directive teaching approach in learning, where the context problems given to students had been completed by the teacher's completion procedure, making the Indonesian students become less independent in resolving context-based problems [6]. Moreover, most teachers in Indonesia have difficulty to design context-based problems [7]. Other research showed that most students in Indonesia have difficulty understanding the problems given in the PISA questions so that students cannot distinguish relevant information and irrelevant information. Students also have difficulty in modeling contextual problems in the form of mathematics. In addition, students are less able to interpret the data given in the PISA questions and difficult to use mathematical concepts and procedures to solve problems [8]. Research conducted by Lestari et al. found that most teachers in Indonesia do not understand mathematics literacy well. This factor causes teachers to rarely provide problem-solving questions in class [9]. Another possibility why Indonesian students have difficulty in solving PISA question is maybe because PISA math problems are less contextual in the student environment in Indonesia. For example, one of the PISA questions in 2012 with the PM921Q01 code about the Penguins where the students in Indonesia never found penguins in their environment. Another example in PISA 2012 that is the problem of MP3 Players coded PM904Q02. In this question, the zeds currency was used which is not familiar with Indonesian students. In fact, zeds do not exist in real life which is only an imaginary currency, so they are not contextual.

In an effort to improve students' ability in Indonesia to solve PISA questions, several studies have been carried out to develop mathematics problems like in PISA [10 - 14]. Ahyan et al. developed several PISA-like mathematics problems for secondary school students, however, they only considered level without considering the content, context, and process [10]. Anisah et al. also developed some PISA-like mathematics problems, but they only considered content, without considering context, process, and level [11]. Charmila and Oktiningrum only concerned about contexts in developing the PISA-like mathematics problems [12, 14], and Kamaliyah only concerned mathematical competency in developing the problems [13]. Thus, we need to develop the PISA- like mathematics problems by taking into account all aspect of PISA domain. In addition, we need to analyze the difficulties of students in solving contextual problems related to their environment. In connection with the above, we have developed PISA-like problems by taking into account the contextual environment of students and the current Indonesian curriculum (2013 curriculum). These PISA-like problems can be used in the teachinglearning process in schools in order to improve students' ability in solving PISA problems. Detail results are reported in this paper.

\section{Research Methods}

In this study, some math problems PISA-like have been developed by using the Tessmer model [15]. First of all, math questions from PISA 2012 were analyzed the domain PISA (context, content, and process). The results were linked to the Indonesian curriculum (2013 curriculum). Based on this analysis, forty-eight math problems PISA-like were developed. All of the PISA-like problems were validated by three experts (PISA expert, math education expert, and language/Bahasa Indonesia expert) and one teacher from junior high school. The next step was small group process in grade nine of junior high school (SMPN 8) Banda Aceh, Indonesia where all validated math problems PISA-like developed previously were given to those junior high school students to obtain some inputs. After that, the field test was conducted in the same school but different class from the small group. The student works were analyzed to find out the students ability in understanding the information given in the problem, understanding what is asked in the questions, solving contextual questions by applying mathematical concepts and processes, and students' ability to make conclusions, arguments including to interpret the results of calculations.

\section{Results and Discussion}

Forty-eight PISA-like math problems have been developed consisting of sixteen questions level one, sixteen questions level two, and sixteen questions level three. Each level consists of all PISA contents (quantity, change, and relationships, space and shape, uncertainty and data) and contexts (personal, societal, scientific, and occupational). The following information about PISA topic, description of the problem, content, context, process, level, and linkages with the Indonesian curriculum (2013 curriculum) are given for each question. The PISA- 
like math problems developed in this study cover almost all the topics in PISA. The themes of the PISA-like questions developed are as follows: apple prices, chicken farm, meeting room, auditorium, rainfall, salary, bread, exchange rate of rupiah with US dollars, exchange rate of rupiah with Malaysian Ringgit, gasoline price, consumption of fuel, power electricity, seminar table, tank order, ceramic installation, roof, aquarium, kite, beam, bedroom, motorcycle sales, flash disk, internet data package, wind velocity, height, and shoe rack.

One of the PISA-like math problems developed in this study is shown in figure 1 . The theme of this question is a chicken farm. The topic is arithmetic operations. The content is quantity, the context is personal, the process is employed, and the level is 2 . This question is related to the 2013 curriculum (to solve social arithmetic problems). The information given in this question is: Mr. Dahlan raises 160 chickens. Each kilogram of feed can be given for 8 chickens per day. The price of chicken feed is IDR 4,000 per kilogram. The question in the problem is to estimate how much it will cost Mr. Dahlan to buy feed for every 30 days.

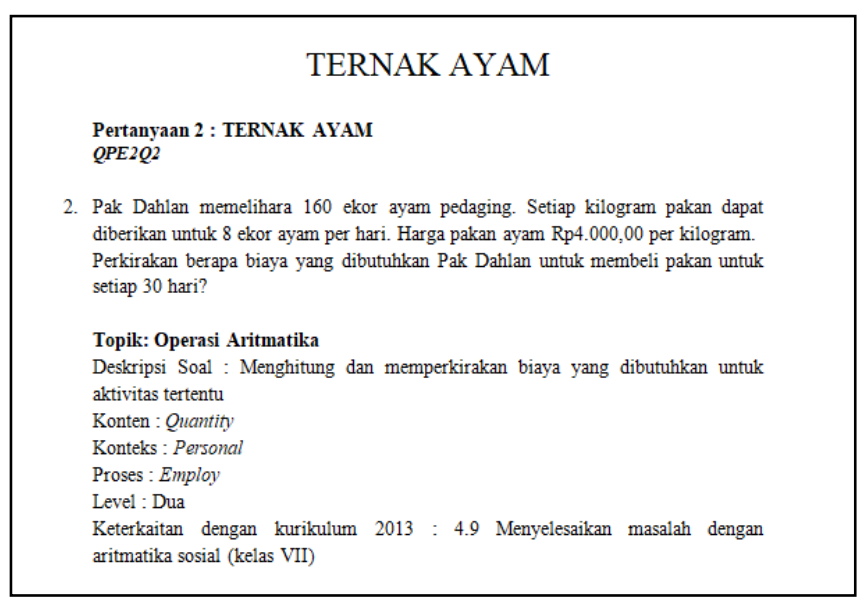

Figure 1: Example of PISA-like math problems

The results of the student questionnaire from the field test showed that $59 \%$ of students strongly agreed and $41 \%$ of students agreed that the appearance of questions is clear and easy to understand (texts, graphics, tables, and pictures). Seventy-one percent of students strongly agreed and $24 \%$ of students agreed that the instructions for all questions (problem) are understandable. Forty-one percent of students strongly agreed and other forty one percent agreed that information given in all questions is clear. Sixty-five percent of students strongly agreed and eighteen percent of students agreed that the questions in the text are given clearly.

During the field test, the questionnaire was also given to several mathematics teachers from junior high school (SMPN 8, Banda Aceh). Fifteen percent of teachers strongly agreed and 50\% agreed to the questions (PISA-like) can provide information about students' abilities. Fifteen percent of teachers strongly agreed and 50\% agreed that PISA-like questions can be used to diagnose the students' ability in mathematical concepts. A number of teachers strongly agree that students can practice answering PISA-like questions to improve their abilities in mathematics. In general, the teachers strongly agree that the questions developed (PISAlike) can be used in the teaching learning process. Thus, the PISA-like questions developed in this study have met the effectiveness criteria.

To analyze the ability of students, students worked on thirteen questions with various levels (level 1, level 2, and level 3) from forty-eight questions developed in this study. The average score of students in understanding the information given in the problems is shown in figure 2 .

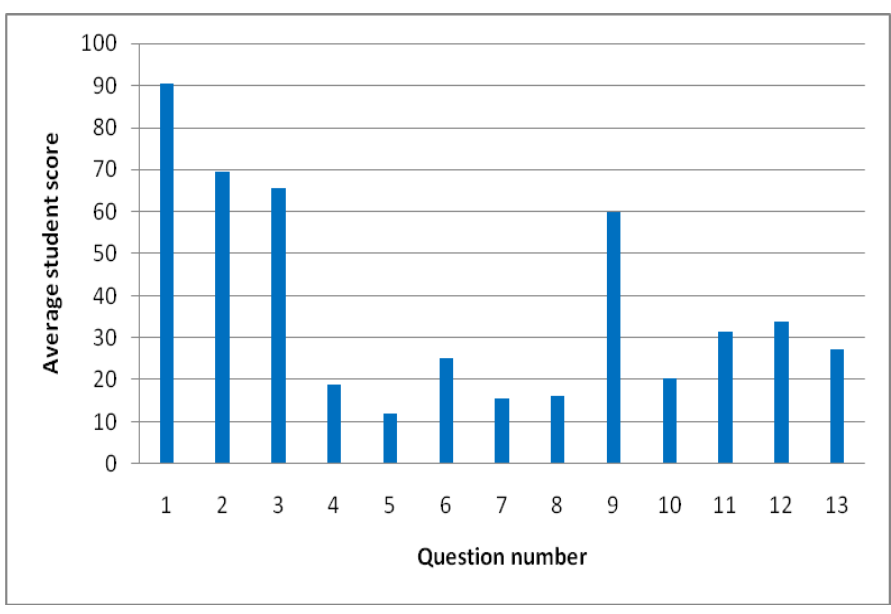

Figure 2: Average student score in understanding the information given in the problems

For question number one, the average score is 90 (scale 100) which is excellent. However, the scores for other questions are low. Only four questions (number 1, 2, 3, and 9) have average scores above 50. While the score for other questions are below 50 . The average score from all thirteen questions is only 37 out of 100 . These results indicated that the ability of students is still very low in understanding the information given in the problems. This finding shows that students' ability to read or to understand a text is still very low. This finding agrees with the previous studies $[6,8]$.

Figure 3 shows the average score of students in understanding the tasks (what is asked) given in the questions. The highest average score is 100 (question number 1). While the lowest average score is 32 (questions number 7 and 8). The average 
scores for all thirteen questions is found to be 64.4 which is above 50 (it can be categorized as good).

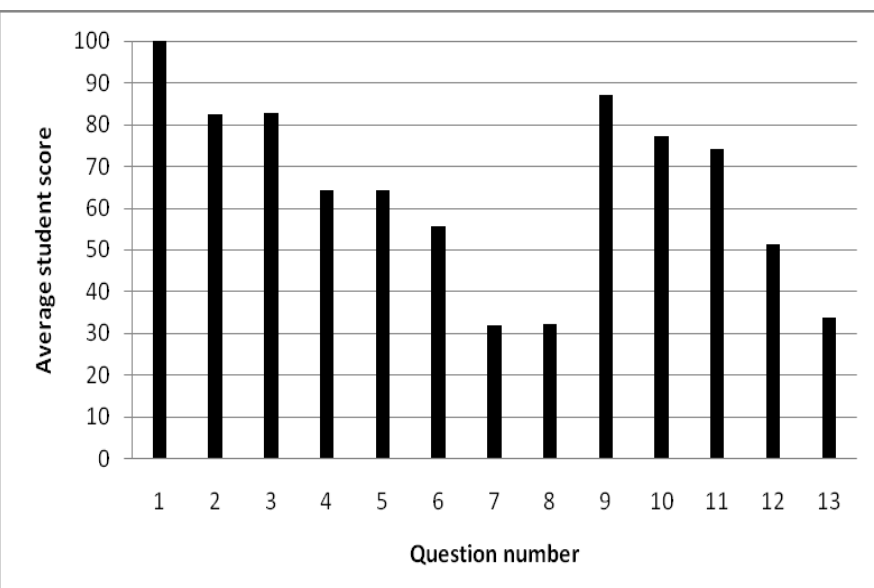

Figure 3: Average student score in understanding the tasks given in the questions

Figure 4 shows the average score of students in understanding the mathematical process.

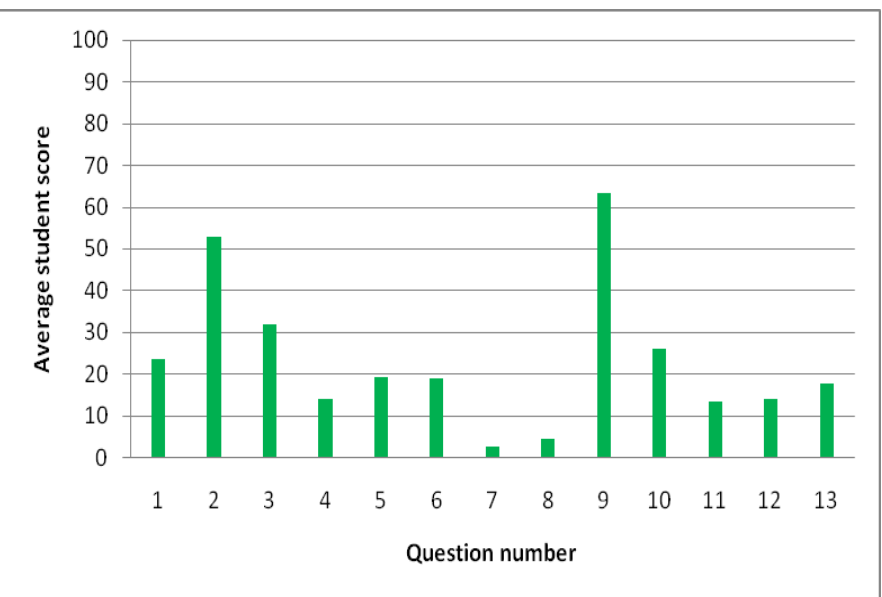

Figure 4: Average student score in the understanding the mathematical process

The highest average score is question number 9 which is above 60. The lowest average score is question number 7 and 8 . The average score for all thirteen questions is 23 which is very low. The results showed that the students have difficulty seriously in solving mathematical problems. Our result is in good agreement with the previous study. Wijaya and Sari found that students' ability to solve problems (mathematical process) was also very low $[6,8]$.

The average score of students' ability in making the conclusion or decoding is shown in figure 5 .

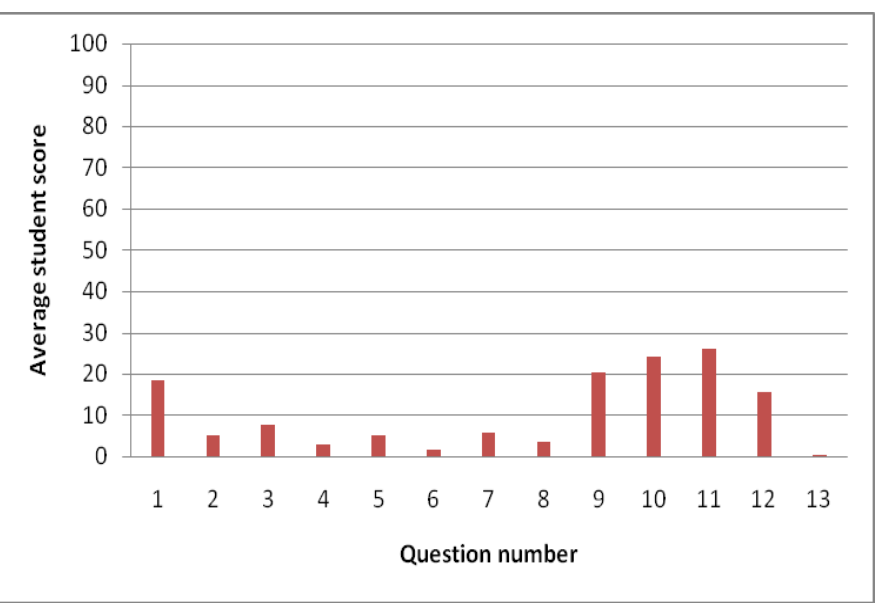

Figure 5: Average student score in understanding making the conclusion

None student has a score above 40 , indicating that the students do not have the ability to make a conclusion or decoding at all. This finding agrees with previous research by Wijaya and Sari where students' ability in decoding is still very low $[6,8]$.

To improve students' ability to work on PISA or contextual questions, the teachers can use the PISAlike questions developed in this study in teaching learning. These PISA-like problems can be inserted in the lesson plan by using the contextual learning model (contextual learning) or other appropriate models (student oriented).

\section{Conclusions}

We have developed forty-eight PISA-like math problems in this study. In general, all of those problems have met the effectiveness criteria. Our study revealed that the ability of students is still very low in understanding the information given in the problems. Other than that, the abilities of students in the mathematical process and decoding are still quite low. In order to improve the student abilities, the PISA-like problems developed in this study can be used by the teachers in the teaching-learning process.

\section{Acknowledgements}

The authors are indebted to Mukhlis Hamid and Erni Maidiyah for their help in reviewing the PISA-like questions. This research did not receive any specific grant from funding agencies in the public, commercial, or not-for-profit sectors.

\section{References}

[1] OECD PISA 2012 “Assessment and analytical framework: mathematics, reading, science, problem-solving and financial literacy" (Paris: OECD Publishing), 2013. 
[2] H. D. Meyer and A. Benavot, "PISA, power, and policy: The emergence of global educational governance," Didcot, UK: Symposium Books, 2013.

[3] M. Wu, "Comparing the similarities and differences of PISA 2003 and TIMSS," OECD Education Working Papers, No. 32, OECD Publishing, 2010. https://doi.org/10.1787/5km4psnm13nx-en

[4] OECD, "PISA 2015Results in focus," (Paris: OECD Publishing), 2016.

[5] OECD, "Mathematics performance (PISA)," 2018. https://doi.org/10.1787/04711c74-en

[6] A. Wijaya, Heuvel-panhuizen, M. Van Den, and M. Doorman, "Identifying ways to improve student performance on context-based mathematics tasks," in CERME 9 - Ninth Congress of the European Society for Research in Mathematics Education, pp. 944-950, 2016. Prague, Czech Republic. https://doi.org/hal01287272

[7] T. Y. E. Siswono, A. W. Kohar, I. Kurniasari and Y. P. Astuti, "Searching for Authentic Context in Designing PISA-like Mathematics Problem: From Indoor to Outdoor Field Experience," Journal of Physics: Conference Series693 12015-12033, 2016.

[8] R. H. N. Sari and A. Wijaya, Mathematical Literacy of Senior High School Students in Yogyakarta. Jurnal Riset Pendidikan Matematika, Jurnal Riset Pendidikan Matematika, 4(41), pp. 100-107, 2017. https://doi.org/10.21831/jrpm.v4i1.10649

[9] N. D. S. Lestari, D. Juniati, and S. Suwarsono, "Preliminary Study: Mathematics' Teacher Conception in Supporting the Integration of Mathematics' Literacy and Mathematics
Teaching and Learning," International Conference on Mathematics: Education, Theory, and Application (ICMETA), Vol. 1, pp. 76-83, 2017.

[10]Shahibul Ahyan, Zulkardi, Darmawijoyo, "Developing Mathematics Problems Based On Pisa Level of Change and Relationships Content," IndoMS-JME, Volume 5, No. 1, January pp. 47-56, 2014.

[11]Anisah, Zulkardi, and Darmawijoyo, "Pengembangan Soal Matematika Model PISA pada Konten Quantity Untuk Mengukur Kemampuan Penalaran Matematis Siswa Sekolah Menengah Pertama," Jurnal Pendidikan Matematika, Vol 5, No. 1, 2011.

[12]N. Charmila, Zulkardi, and Darmawijoyo, Pengembangan Soal Matematika Model PISA Menggunakan Konteks Jambi, Jurnal Penelitian dan Evaluasi Pendidikan 20, pp. 198-207, 2016.

[13]Kamaliyah, Zulkardi, and Darmawijoyo, Developing the sixth level of PISA-like mathematics problems for secondary school students, Journal on Math Education 4, pp. 928, 2013.

[14]W. Oktiningrum and Y. Hartono, "Developing PISA-" Like" Mathematics Task with Indonesia Natural and Cultural Heritage as Context to Assess Students Mathematical Literacy," Journal on Mathematics Education7, pp. 1-10, 2016.

[15]M. Tessmer, Planning and Conducting Formative Evaluations, Kogan Page Limited, London, England, 1993. 